\title{
A INFLUÊNCIA DA PARTICIPAÇÃO POPULAR NAS POLÍTICAS PÚBLICAS PARA A EDUCAÇÃO INFANTIL NO MUNICÍPIO DO RECIFE $^{1}$
}

\author{
Joyce Danielly Pedrosa da Silva² \\ Ana Lúcia Felix dos Santos ${ }^{3}$
}

\section{RESUMO}

O presente artigo discute a relação entre as políticas públicas para educação infantil e as possibilidades de interferência da participação popular nas ações que são de responsabilidade dos municípios. Tem como objetivo analisar a influência da participação popular nas decisões para política educativas nessa área, considerando a concepção de infância e suas especificidades. Toma como espaço de estudo o município do Recife e adota como campo empírico documentos concernentes ao assunto. Procurou considerar os avanços e contradições que permearam $o$ processo de reconhecimento da educação infantil como direito da criança. Os dados revelaram que a participação das comunidades e seus representantes foi determinante para a construção do perfil das ações para a educação infantil municipal.

Palavras-chave: Políticas Educacional. Participação Popular. Educação Infantil. Recife.

\footnotetext{
${ }^{1}$ A pesquisa que originou este artigo contou com o apoio da FACEPE - Fundação de Amparo à Ciência e Tecnológico Estado de Pernambuco

${ }^{2}$ Mestre em Educação pela Universidade Federal de Pernambuco - UFPE. ORCID: http://orcid.org/0000-0002-0562-5339. Email: joyce.pedrosa@hotmail.com

${ }^{3}$ Doutora em Educação pela Universidade Federal de Pernambuco- UFPE. Professora da Universidade Federal de Pernambuco- UFPE, no Programa de Pós-Graduação em Educação/UFPE. ORCID: http://orcid.org/0000-0002-1040-2156 Email: ana.fsantos@ufpe.br
} 


\section{THE INFLUENCE OF POPULAR PARTICIPATION IN EARLY CHILHOOD EDUCACTION'S PUBLIC POLICIES IN THE CITY OF RECIFE}

\section{ABSTRACT}

This article discusses the correlation between early childhood education's public policies and the possibilities of popular participation interference in actions which are the city's responsibility. It aims to analyze the influence of popular participation in decisions for educational policies in this field, considering the concept of childhood and its specificities. Takes the city of Recife as a study space, and documents concerning the subject as an empirical field. It pursued to consider the advances and contradictions which permeated the recognition process of early childhood education as a child's right. The data revealed that the participation of communities and their representatives was decisive in developing the action's profile for municipal early childhood education.

Keywords: Educational Policies. Popular Participation. Childhood Education. Recife.

\section{LA INFLUENCIA DE LA PARTICIPACIÓN POPULAR EM LAS POLÍTICAS PÚBLICAS PARA LA EDCACIÓN DE LA PRIMERA INFANCIA EN EL MUNICÍPIO DE RECIFE}

\section{RESUMEN}

Este artículo analisa la relación entre las políticas públicas para la educación de la primera infancia y las possibilidades de la interferência del participación popular en acciones que son responsabilidade de los municípios. Su objetivoes analizar la influencia de la participación popular em las decisiones del política educativa para primera infância, considerando la concepción de la infância y sus especificidades. La ciudad de Recife fuera lo espacio del estúdio y adopta documentos empíricos sobre el tema. Intentó 
considerar los avances y contradicciones que permearon el proceso que he reconocido la educación de la primera infancia como un derecho del niño. Los datos revelaron que la participación de las comunidades y sus representantes fue determinante en la construcción del perfil de acciones para la educación infantil municipal.

Palabras Clave: Políticas Educativas, Participación Popular, Educación Infantil, Ciudad de Recife

\section{INTRODUÇÃO}

A relação entre a implantação de políticas educacionais para educação infantil e as possibilidades da participação popular é o foco deste estudo. Ao considerar a concepção de infância e as ações voltadas para essa etapa de formação, buscamos observar a influência direta da participação popular, constituída aqui pelas comunidades e seus representantes, e demos destaque à perspectiva de gestão democrática como possibilidade norteadora para a gestão da educação contemporânea.

Para entender esse movimento e estudar as políticas para educação em curso no Brasil, é necessário explorar o modelo federalista que marca a atual organização sociopolítica, porque é nesse contexto que se configuram as responsabilidades sobre as políticas sociais, incluindo a educação como bem público. A partir da Constituição de 1988, a educação da infância foi reconhecida como obrigatória e outros dispositivos legais trouxeram os contornos para a educação nacional de forma mais específica, como é o caso da Lei de Diretrizes e Bases da Educação Nacional (LDB) - n 9394/96, que aponta os princípios federalistas:

Art. $5^{\circ} \mathrm{O}$ acesso à educação básica obrigatória é direito público subjetivo, podendo qualquer cidadão, grupo de cidadãos, associação comunitária, organização sindical, entidade de classe ou outra legalmente constituída e, ainda, o Ministério Público, acionar o poder público para exigi-lo. (BRASIL, 1996c). 
E no Art. 11, Inc. V, esclarece que o município deve:

Oferecer a educação infantil em creches e préescolas, e, com prioridade, o ensino fundamental, permitido a atuação em outros níveis de ensino somente quando estiverem atendidas plenamente as necessidades de sua área de competência e com recursos acima dos percentuais mínimos vinculados pela Constituição Federal à manutenção e desenvolvimento do ensino. (BRASIL, 1996c)

Com vistas à organização e planejamento da educação nacional, a legislação remete à necessidade de construção dos planos nacionais de educação. Na atualidade, temos a Lei $n^{\circ}$ 13.005/2014, que cria o Plano Nacional de Educação (PNE), com vigência decenal 2014-2024, e revela alguns avanços no âmbito do tratamento dado à educação infantil. Mesmo considerando as dificuldades de sua implantação neste momento do cenário nacional, é necessário destacar que os entes federados foram obrigados a construir seus próprios planos, devendo contar com ampla e irrestrita participação dos representantes da comunidade escolar e demais representantes da sociedade civil. Nesse cômputo, houve destaque para a responsabilidade municipal sobre a educação infantil e o ensino fundamental, que, em parceria com o estado, deve propor os objetivos e a execução das metas na legislação vigente.

Destacamos que as orientações para decisões colegiadas entre o poder público e a sociedade civil não são de hoje e possuem força suficiente para formular e legislar sobre os interesses do público. A representatividade adquirida ao longo da evolução democrática brasileira trouxe à tona um campo de lutas e tensões, mas que proporciona o exercício da democracia, neste momento tão ameaçada.

Nesse contexto, buscamos levantar elementos que pudessem revelar esse movimento democrático no interior das discussões e nas decisões sobre a política para educação infantil em âmbito municipal. Daí tomamos como exemplo o caso do município de Recife e nos debruçamos sobre determinados documentos, para buscar respostas à seguinte questão: qual a relação entre a comunidade e o município 
na tomada de decisões sobre os rumos das políticas para educação infantil?

Nessa abordagem, oportuniza-se a discussão sobre a participação popular, representada pela atuação das lideranças nas comunidades, dos professores e das entidades de classe, que ganhou contornos ao longo da construção da identidade dos municípios.

Como base para a pesquisa qualitativa, na qual "todos os dados da realidade são considerados importantes" (LUDKE; ANDRÉ, 1986, p. 12), fizemos a análise documental, por meio da coleta de dados, que se deu a partir da necessária e desafiadora investida sobre os documentos que compõem o cenário das políticas educativas no município e as legislações nacionais, obedecendo uma certa ordem. Corroborando a nossa escolha, diante da infinidade de fontes documentais, Bardin (2009, p. 121) afirma que "a escolha de documentos depende dos objetivos, ou, inversamente, o objetivo só é possível em função dos documentos disponíveis". Assim, elencamos as seguintes fontes de dados sobre o município: Caderno de Educação Municipal. 0 povo mesmo fala, escreve... conta sua história. Um modo de praticar educação. Ano 01, n 2 (Recife, dezembro de 1988); Lei orgânica do município, promulgada em 04 de abril de 1990; Lei $n^{\circ}$ 15.547/ 91 - Plano Diretor de Desenvolvimento da Cidade do Recife; Caderno Melhoria da Qualidade de Ensino, fóruns-debate, série Caderno Municipal de Educação SEC/PCR, 1993; Lei no 18.147/2015 - Plano Municipal de Educação. Quanto à legislação nacional, utilizamos a Constituição Federal de 1988 e os Planos Nacionais - Lei no 10.172/01 (PNE 20012010) e Lei $n^{\circ}$ 13.005/14 (PNE 2014-2024).

O artigo está organizado de forma a propor discussões sobre as políticas públicas e políticas educacionais nos municípios, associando-as ao entendimento sobre o conceito de política e observando a atuação do Estado e a participação da sociedade nesse processo. Posteriormente, tratamos sobre a infância e a educação infantil como uma conquista dos direitos da criança, pontuando alguns aspectos relevantes da história e da política para essa etapa da educação. Por fim, discutimos um pouco a experiência da cidade do Recife no tocante à participação da comunidade na elaboração de políticas para educação infantil. 


\section{POLÍTICA, POLÍTICAS PÚBLICAS E POLÍTICA EDUCACIONAL NOS MUNICÍPIOS}

Tendo a discussão sobre política como balizadora em nossa pesquisa, compreendemos a importância e necessidade de entendêla e conceituá-la em seu mais amplo sentido. Para isso, trazemos a perspectiva de Bobbio (1995), que discute a temática em sua relação com o exercício de poder, o perfil político, a atuação do Estado e a força destes segmentos na vida dos homens.

O significado clássico e moderno de política derivado do adjetivo originado de pólis (politikós), que significa tudo o que se refere à cidade e, consequentemente, o que é urbano, civil, público, e até mesmo sociável e social, o termo política se expandiu graças à influência da grande obra de Aristóteles, intitulada Política, que deve ser considerada como o primeiro tratado sobre a natureza, funções e divisão do Estado, e sobre as várias formas de governo, com a significação mais comum de arte ou ciência do governo. (BOBBIO, 1995, p. 954).

A discussão sobre as políticas públicas encontra raízes na definição de política. Neste sentido, Secchi (2016) discute essa concepção a partir de Bobbio (2002), afirmando que a política acontece na ação direcionada do homem, que utiliza as ferramentas necessárias para obter e manter seu poder de atuação sobre os outros homens. Esse poder do homem exercido sobre outros homens carrega a dimensão integrada entre a decisão e a ação.

No entanto, destacamos que o conceito de política pública tem diferentes entendimentos e carrega concepções que precisam ser explicitadas. Para tanto, Muller e Surel (2002) ofertam os conceitos desta distinção.

Com efeito, este termo cobre, ao mesmo tempo, a esfera da política (polity), a atividade política (politics) e a ação pública (policies). A primeira faz a distinção entre o mundo da política e a sociedade civil, podendo a fronteira entre os dois, sempre 
fluida, variar segundo os lugares e as épocas; a segunda designa a atividade política em geral (a competição pela obtenção dos cargos políticos, o debate partidário, as diversas formas de mobilização...); a terceira acepção, enfim, designa o processo pelo qual são elaborados e implementados programas de ação pública, isto é, dispositivos políticos-administrativos coordenados em princípio em torno de objetivos explícitos. (MULLER; SUREL, 2002, p.10)

Os autores discutem sob a perspectiva inicial das políticas públicas, de essência tradicionalista e de caráter delimitado, porque os primeiros entendimentos sobre a matéria aconteceram sob a luz das ciências administrativa e do direito.

Nessa perspectiva tradicional, as políticas públicas se encontravam delimitadas, segundo sua inscrição num território dado e/ou um setor econômico tornando-se esta última noção, pouco a pouco, o principal modo de distinção. (MULLER; SUREL, 2002, p. 14)

Ao modificar-se a partir da conceituação sociológica, a formulação das políticas públicas tornou-se um espaço de trocas entre os atores, contendo subsistemas; nessa interação, as relações de poder se dão de forma mais regular e contínua, o que resulta na obtenção de recursos. "Para que se esteja na presença de uma política, é necessário que seja igualmente definido, pelo menos como tendência, um quadro geral de ação." (MULLER; SUREL, 2002, p. 15)

A definição do que é uma política pública é um terreno bastante delicado, pois "qualquer definição de política pública é arbitrária" (SECCHI, 2016, p. 2). Diante disso, o autor traz a seguinte reflexão:

Uma política pública possui dois elementos fundamentais: intencionalidade pública e resposta a um problema público; em outras palavras, a razão para o estabelecimento de uma política pública é o tratamento ou a resolução de um problema 
entendido como coletivamente relevante. (SECCHI, 2016, p. 2)

Embora Secchi (2016) afirme que seria tendencioso definir o que é uma política pública, no Estado Moderno ainda há a interpretação que ela é fruto do monopólio das decisões dos atores estatais, onde o Estado formula as leis, cabendo ao povo apenas o seu cumprimento. Por outro lado, a abordagem multicêntrica inclui as organizações privadas, além das não governamentais, organizações internacionais e demais componentes que pertencem as redes de políticas públicas, permitindo diversas origens nas ações decisórias. A partir disso, distingue-se a concepção de políticas públicas como as ações postas sob a responsabilidade do Estado com a participação de diversos segmentos.

Nessa abordagem, identificamos a permissão da participação popular, legitimada na representatividade das comunidades nas decisões:

Do ponto de vista normativo, compartilhamos da convicção que o Estado deve ter seu papel reforçado, especialmente para enfrentar problemas distributivos, assimetrias e outras falhas de mercado. No entanto, do ponto de vista analítico, acreditamos que o Estado não é o único a protagonizar a elaboração de políticas públicas. (SECCHI, 2016, p. 3)

Nesse contexto, inclui-se o esclarecimento sobre a dimensão das ações executadas, já que na maioria das vezes entende-se que uma política pública age apenas no campo macro, fato que nivelariam as regiões e as comunidades. Dessa forma, estariam excluídos os problemas mais específicos, das mais diversas naturezas envolvendo as comunidades, impossibilitando a prática de influência do poder local para resolver seus problemas públicos.

Ao problematizarmos as políticas públicas, destacamos que sua formulação não é exclusividade dos representantes do Estado; na contemporaneidade, sua elaboração deve acontecer de forma coletiva para atender às necessidades da sociedade. Nessa 
construção, a participação popular exerce seus direitos adquiridos por força de lei, reforçando o conceito de cidadania.

A cidadania, neste novo milênio, vem ressurgindo, pois esse conceito está intrinsecamente ligado à ideia de participação popular e justiça; assim, a cidadania passa hoje por novos desafios em face de diversos fatores econômicos e políticos que fomentam esse descontentamento da população. (HERMANY; FRANTZ, 2008, p. 2)

Nesse contexto, a cidadania de forma ativa é capaz de conduzir e dar autonomia aos cidadãos, tornando-os peças-chave nas decisões da sociedade.

É preciso verificar e indagar a respeito de que tipo de cidadãos efetivamente somos e se realmente somos sujeitos de direito ou simples surgimento da modernidade. Nota-se que a sociedade civil, hoje, começa a buscar os seus direitos diante do Estado, pois assim começa a dar origem a cidadania ativa. (HERMANY; FRANTZ, 2008, p. 6)

Os municípios se configuram como o local onde se legitima o exercício da cidadania, através dos debates com a sociedade e a proposição de ações. É o local onde se facilita a proximidade dos cidadãos com representantes do governo, ampliando a participação nas questões mais próximas e fortalecendo a democracia.

Essa proximidade encontra raízes nos direitos e deveres dos cidadãos, legitimando a democracia, principalmente quando o Estado age com neutralidade e transparência na gestão dos recursos públicos; "assim o Estado passa a ser entendido como ente regulador, indutor e garantidor da ordem pública e não mais como um poder distanciado de seus comandados, mas que começa a pensar nas necessidades de seus comandados" (HERMANY; FRANTZ, 2008, p. 8).

Consequentemente, essa interação entre a comunidade local e o Estado amplia e fortalece a gestão pública compartilhada. Para isso, é necessário que atores de transformação oportunizem a universalização dos direitos, pois as experiências demonstram dificuldades em efetivar esse direito. Conforme já questionava 
Goulart (2006, p. 51), "em que medida uma nova esfera pública é capaz de redefinir as relações entre Estado e sociedade civil de uma perspectiva democratizante?". A perspectiva é que os movimentos da sociedade civil devem promover atividades que viabilize a democratização de valores e normas para a coletividade.

Independente dos juízos que venham a se formar ou abstraindo as diferenças conceituais sobre o entendimento da sociedade civil brasileira, sua importância e incidência na vida política nacional são evidentes. Permeiam essa concepção valorativa duas ideias básicas: primeiro, que, também na sociedade civil, operam relações de poder; e segundo, que a luta social pode e deve se traduzir em direitos. (GOULART, 2006, p. 53)

Nessa perspectiva, entendemos a relevância da participação representativa da sociedade civil nas deliberações sobre as políticas educacionais, o que não exclui a cobrança dos demais atores quanto às decisões tomadas, afinal a deliberação exige retorno quanto às demandas postas em discussão.

Buscamos elementos dessa participação na elaboração da política para educação infantil no município do Recife, assim é relevante que tratemos um pouco sobre a educação infantil.

\section{A INFÂNCIA E A EDUCAÇÃO INFANTIL COMO ELEMENTOS DA POLÍTICA EDUCACIONAL}

O contexto histórico sobre a infância na sociedade traz as marcas de quando as crianças eram consideradas apenas componentes comuns dos grupos de família e das comunidades, consequentemente incorporadas aos costumes desses grupos. Com o avanço da modernidade, surgiram alguns questionamentos que levaram a sociedade a perceber a criança com suas peculiaridades, que remetem a medidas de proteção, igualdade, notoriedade e cuidados especiais.

O reconhecimento da infância como etapa da formação humana, composta de especificidades, é um advento bastante 
recente na história mundial. Nos primeiros registros, não havia indícios de que os representantes da sociedade tinham alguma consideração sobre a existência das crianças e principalmente das suas necessidades.

Até por volta do século XII a arte medieval desconhecia a infância ou não tentava representála. É difícil crer que essa ausência se devesse à incompetência ou à falta de habilidade. É mais provável que não houvesse lugar para a infância nesse mundo. (ARIÉS, 2006, p. 17)

Por volta do século XIV, as crianças começaram a se destacar nas pinturas em diversas situações; no entanto, é prudente analisar o contexto desta participação: ora como uma participante da vida adulta, ora como representando do "engraçado". Lembrando que nesse período a mortalidade infantil era algo natural, em decorrência das péssimas condições demográficas, algo que se estendeu de meados do século XIII ao XVII. Ao trazer a discussão para os tempos mais recentes, no Brasil, os registros históricos evidenciam que no final dos anos de 1980, durante o processo de redemocratização, houve várias mudanças na política educacional brasileira. Esse movimento fez surgir discussões em campos ideológicos da política, da sociologia e da psicologia, impactando a educação infantil brasileira. Assim, houve mudanças nos paradigmas reconhecendo a infância como uma etapa da formação humana com características bastante específicas.

No caso brasileiro, a infância e a educação infantil trazem os sinais do perfil assistencialista, que marca a educação para essa etapa, voltada às comunidades menos favorecidas, na tentativa de compensar as dificuldades da classe trabalhadora em ter acesso à educação infantil, marcada por fragilidades e improvisos.

Com as mudanças na sociedade brasileira, incluindo as lutas de classe e as mudanças no perfil econômico - quando a camada da população mais pobre passou a ser economicamente ativa -, emergiu a carência do atendimento ao público infantil e revelou a necessidade da escola pública e, consequentemente, da pré-escola, tendo como desafio a reflexão sobre a concepção de infância e a consideração de 
suas especificidades. Esse cenário acompanhou a evolução do sistema educativo no nosso país até recentemente. Como exemplo podemos apontar a existência de fragilidades no tratamento da educação infantil, evidenciado no período de transição do regime ditatorial para a democracia, que incluem a falta de investimentos, a influência de organizações internacionais e a vulnerabilidade no sentimento de pertença nacional e regional, debilitando a educação infantil nacional.

A criança, peça mais importante desse cenário, é invisível. Não há atenção ao desenvolvimento de suas características, que por muito tempo foram sabotadas. Subjugou-se a formalização de uma educação eficaz para as crianças, onde sua formação holística fosse respeitada. A grande maioria das políticas públicas para a infância no período pós-ditatorial brasileiro se identifica apenas com 0 atendimento à classe mais pobre e com a expansão do ensino fundamental.

Na promulgação da Constituição Federal de 1988, a educação infantil passou a ser reconhecida como direito da criança, indicando o fortalecimento das políticas educacionais para a infância. No entanto, diversas vulnerabilidades persistiram, entre elas a vinculação da educação infantil, creche e pré-escola às condições sociais do público atendido, assim como a fragilidade e a inconsistência de destinação de recursos financeiros. O ensino nesse processo se caracterizou, em certa parte, pela vivência da criança em um ambiente adaptado, desprezando a concepção de que educar e cuidar são indissociáveis.

Esse movimento revelou a necessidade de práticas para fortalecer as parcerias com as comunidades, especificamente as associações de mães e moradores, que tinham como finalidade a proteção da criança no período em que as mães (e pais) estavam no trabalho. Percebeu-se, então, as comunidades como representantes da participação do poder local na rotina dos primeiros atendimentos na educação infantil. Tal participação se tornou determinante nas decisões das políticas públicas para esse setor, construindo um cenário de lutas e conquistas que atendem às especificidades das comunidades. 
Do ponto de vista da educação infantil como elemento da política educacional, lembramos que a educação nacional possui a prerrogativa de ser um bem público, direito dos cidadãos e de responsabilidade do Estado e tem suas raízes na Declaração Universal dos Direitos Humanos de 1948. A responsabilidade sobre a educação infantil e o ensino fundamental é dos municípios, que, em parceria com o Estado, deve propor os objetivos e a execução das metas na legislação vigente.

Para dar conta da oferta da educação com qualidade e tentar garantir que as incumbências de cada ente federado sejam realizadas, a legislação prevê que eles devem materializar suas políticas para educação tomando como princípio o regime de colaboração. Com base nesse princípio, cada ente federativo possui uma parcela de responsabilidade sobre a educação nacional, conforme o Art. 211, da Constituição Federal de 1988.

\begin{abstract}
Art. 211. A União, os Estados, o Distrito Federal e os Municípios organizarão em regime de colaboração seus sistemas de ensino: $\S 2^{\circ}$ Os Municípios atuarão prioritariamente no ensino fundamental e na educação infantil. (Redação dada pela Emenda Constitucional $n^{\circ} 14$, de 1996); § $3^{\circ}$ Os Estados e o Distrito Federal atuarão prioritariamente no ensino fundamental e médio. (Incluído pela Emenda Constitucional $n^{\circ} 14$, de 1996) (BRASIL, 2016)
\end{abstract}

A partir dessa determinação, as expectativas diante da ação pública no campo da educação são dispostas nas metas e objetivos presentes nas legislações vigentes, em especial nos planos de educação. Há uma interdependência entre os entes federados no processo de planejamento e na oferta da educação nacional. Isso se revela importante para o entendimento dos rumos das políticas para educação infantil no país e nos municípios brasileiros.

Um dos elementos fundamentais para organização da educação nacional consiste no Plano Nacional de Educação, que determina que os estados e municípios tenham a responsabilidade de elaborar seus Planos Educacionais ou reestruturar as legislações já existentes utilizando estratégias convenientes à região e 
considerando as políticas sociais e culturais, além da ampla participação dos diversos segmentos da sociedade.

No enquadramento da educação como política pública, o próximo passo foi a implementação e execução da educação nacional. Na confirmação dessa orientação, está a Lei no 10.172 , de 09 de janeiro de 2001, que instaurou o primeiro Plano Nacional de Educação para o período 2001-2010, já indicando algumas relevâncias no atendimento da educação infantil, ao trazer a importância do atendimento à criança pequena e do papel fundamental na formação e no desenvolvimento da inteligência como referência nas demais épocas da vida.

No entanto, entre as dificuldades para fortalecer as políticas educativas brasileiras, está o financiamento. Assim, como referência inicial, a Lei no 9.424, de 24 de dezembro de 1996, instituiu o Fundo de Manutenção e Desenvolvimento do Ensino Fundamental e de Valorização do Magistério (Fundef). Essa legislação, que excluiu o financiamento específico para a educação infantil, reafirmou a fragilidade no seu reconhecimento enquanto etapa da educação básica. Consequentemente, as políticas para a educação infantil enfraqueceram.

Dando prosseguimento às políticas educacionais no Brasil, foi sancionada a Lei ${ }^{\circ} 13.005$, de junho de 2014, estabelecendo o Plano Nacional de Educação 2014-2024 e certificando algumas mudanças e permanências nas orientações. Apontando uma permanência, o plano em vigência (2014-2024) determina que o Distrito Federal, estados e municípios têm o prazo de um ano para a elaboração de seus planos ou adequação às suas legislações vigentes, seguindo os princípios determinados e devendo contar com a ampla participação dos representantes da comunidade escolar e demais representantes da sociedade civil.

As distinções estão na criação de novas instâncias e estratégias para o cumprimento das metas estabelecidas, prevendo a existência de uma conferência nacional, seguida de conferências distrital, estadual e municipal com periodicidade de dois anos, conectados ao Fórum Nacional de Educação, instância concebida pelo Ministério da Educação para conduzir as atividades no 
cumprimento do PNE. Quanto à relação do PNE (2014-2024) com a educação infantil, temos a seguinte determinação:

Meta 01: universalizar, até 2016, a educação infantil na pré-escola para as crianças de 4 (quatro) a 5 (cinco) anos de idade e ampliar a oferta de educação infantil em creches de forma a atender, no mínimo, 50\% (cinquenta por cento) das crianças de até 3 (três) anos até o final da vigência deste PNE. (BRASIL, 2013, p. 2)

Sabendo que o PNE 2014-2024 carece de recursos para efetivar suas metas, temos a Lei $n^{\circ} 11.494$, de 20 de junho de 2007, que estabelece o Fundo de Manutenção e Desenvolvimento da Educação Básica e de Valorização dos Profissionais da Educação (Fundeb), que propõe a reorganização sobre o financiamento das ações para a educação, incluindo, desta vez, aportes para a educação infantil.

A previsão é o reforço no alinhamento ao regime de colaboração a fim de ampliar as redes de atendimento à educação infantil. Porém, para a garantia de recebimento destes recursos, deverá estar em vigência o Plano Estadual e/ou Municipal de Educação, aprovado por força de lei.

Nesse contexto, avaliamos que a importância está tanto na preservação das características inerentes da educação infantil, com a garantia dos atendimentos na faixa etária da creche (0 a 3 anos) e na pré-escola (4 a 5 anos), assegurando qualidade e acesso das crianças, como no encorajamento e nas condições para usufruto na educação infantil em creches e pré-escolas em tempo integral, obedecendo às Diretrizes Curriculares Nacionais.

\section{A PARTICIPAÇÃO POPULAR E AS POLÍticAs PARA A EDUCAÇÃO INFANTIL: a experiência do município do recife}

O município do Recife, local de nossa pesquisa, possui entre suas características elementos de participação das comunidades locais no que diz respeito às questões sobre educação, incluindo a educação infantil. Antes do surgimento das legislações nacionais 
fazerem essa indicação, o Recife já utilizava dessas estratégias, segundo os registros documentais à época.

A construção da identidade educacional do Recife destaca a conquista de sua autonomia através de muitas lutas e conflitos, o que possibilitou diversos avanços, entre eles o atendimento aos anseios dos atores que compõem a educação municipal. Corroborando essa afirmativa, nos registros históricos percebe-se a presença marcante das comunidades durante o trajeto da elaboração do perfil da educação infantil do município. O alinhamento com as periferias resultou, ao final dos anos 1980, durante a reabertura democrática, em um período em que a educação infantil municipal contou com a participação ativa das comunidades, que exerceram forte influência no atendimento às crianças e também na destinação dos recursos. Nesse período, as ações conjuntas entre as secretarias de educação e a comunidade demonstravam articulação, sem que necessariamente naquela época houvesse a indicação da existência de um plano municipal.

Isso porque o atendimento às crianças em educação infantil na cidade, no período de 1970 a meados da década de 1980, compreendia o que era assegurado através de escolas e creches, com um atendimento amplo às comunidades através do movimento de escolas comunitárias, que naquela época contavam com várias professoras e tinham o apoio da Arquidiocese de Olinda e Recife trabalhando junto à prefeitura e com o apoio de lideranças femininas das próprias comunidades.

Essa iniciativa do município do Recife se revela nos registros históricos de debates que ocorreram antes mesmo da promulgação da Constituição Federal de 1988 e oportunizaram que, além dos representantes governamentais, as comunidades participassem ativamente de encontros que pautaram soluções para o problema do atendimento das crianças pequenas em creches e pré-escolas.

Alguns frutos surgiram desses encontros, como o Documento sobre a pré-escola municipal: definição política e proposta curricular (1988), um indicativo dos primeiros esforços para os atendimentos da educação infantil municipal, e um esboço para as primeiras políticas públicas para a pré-escola, registrado em Caderno de Educação Municipal. 0 povo mesmo fala, escreve... 
conta sua história. Um modo de praticar educação, em dezembro de 1988, objetivando a formação da cidadania das crianças.

\begin{abstract}
A pré-escola oferecida às crianças das camadas populares deve fazê-las, desde cedo, adquirir novas formas de expressão e reconhecimento do seu mundo, de seu desenvolvimento do pensamento lógico-matemático e das habilidades de refletir, lidar e transformar o mundo físico-social sendo, portanto, o seu objetivo principal favorecer o processo de alfabetização dessas crianças. (RECIFE, 1988a, p. 14)
\end{abstract}

Em uma das estratégias, destacamos a restruturação do Conselho Municipal de Educação da Cidade do Recife, composto por representantes de diversos segmentos da sociedade, conforme o Art. $3^{\circ}$, da Lei Municipal $n^{\circ}$ 14.105/79: Sindicato dos Professores do Estado de Pernambuco, rede particular de ensino/rede municipal, câmara municipal do Recife, notório saber e experiência em Educação, Presidente da Fundação Guararapes, pais e mestres e rede oficial de ensino.

$\mathrm{Na}$ análise de um dos relatórios, datado do período de outubro de 1984 a junho de 1985, descreve-se uma das reuniões do Conselho Municipal como o início dos trabalhos no tocante às políticas públicas que deveriam ser adotadas no município.

No Recife, os registros alegam que os atendimentos voltados à educação infantil eram articulados entre a secretaria de educação e a de assistência social, com vieses de uma educação assistencialista. Também são reconhecidas as lideranças femininas, diante do avanço das mulheres no mercado de trabalho, na defesa dos atendimentos a todas as crianças, não apenas aquelas que fossem da classe trabalhadora, além de prezar pela qualidade e as especificidades da infância. Assim, as demandas de atendimento à educação infantil foram ampliadas no decorrer dos avanços da sociedade, e a condição da responsabilização do município para a oferta e garantia trouxe a prática de promoção de debates entre os diversos segmentos sobre os rumos da educação municipal. A definição do perfil da política educacional do Recife possui registros que trazem como pano de 
fundo as estratégias políticas do município, feitos pelas pessoas que contribuíram ativamente nessa discussão.

Nesse período, a participação das comunidades era materializada através do Programa Prefeitura nos Bairros, que objetivava promover discussões sobre ações da prefeitura, através da escuta ativa das comunidades. A partir disso, surgiram as escolas comunitárias, detentoras de representação na gestão municipal e onde aconteciam os atendimentos da educação infantil prevalecendo a estrutura popular e a harmonização entre diversos órgãos.

Dando prosseguimento às mudanças da sociedade, a transição da educação assistencialista para a educação na perspectiva do direito, acontece após a promulgação da Constituição Federal de 1988. Entende-se que, ao adquirir status de direito público, paulatinamente as secretarias de educação assumiram a autonomia observando suas especificidades.

Em seguida, é promulgada a Lei Orgânica do Município, em 04 de abril de 1990, tornando-se o marco regulatório das ações municipais. No decorrer dos 30 anos de sua existência, houve algumas alterações para adequação às demandas da sociedade em expansão. Entre os itens que compõem o dispositivo, está a Emenda n ${ }^{\circ}$ 21/2007, da Comissão Especial de Revisão, que propõe novas ações para balizar a política sobre a educação municipal.

O documento traz a indicação sobre as responsabilidades do município e dos entes participantes nas decisões, descritas no Título $\mathrm{V}$ - desenvolvimento urbano e das políticas públicas municipais. Especificamente, o Capítulo VI preceitua sobre a política de educação, destacando o Art. 131, com a seguinte determinação:

A educação, direito de todos e dever do Estado e da família, será promovida e incentivada pelo município em colaboração com a União, o Estado de Pernambuco e a sociedade, visando ao pleno desenvolvimento da pessoa, seu preparo para o exercício da cidadania e sua qualificação para o trabalho. (RECIFE, 1990) 
Nesse extrato da lei, identifica-se a participação da sociedade nas atividades que discutem a política educacional do município, enfatizando a presença do local.

Outro fato bastante importante da Lei Orgânica do Recife está no Art. 135, que regulamenta o Conselho Municipal de Educação, formado por orientações contidas no Plano Diretor de Desenvolvimento da Cidade. A configuração do conselho foi composta por competências que incluem o funcionamento da educação municipal com a participação popular e a gestão democrática, conforme descrita em lei.

Assim sendo, o antigo conselho, criado em 1971, foi reformulado através de um projeto de lei elaborado de forma participativa pelos representantes das entidades mais representativas atuantes do município: câmara de vereadores, equipe técnica da Secretaria de Educação, Associação de Educadores das Escolas Comunitárias, Sindicatos de professores, Ong's de assessoria à Educação Popular, Centro de Educação da Universidade Federal, além de contar com um membro representante de cada comissão regional de Educação, para assegurar o caráter regional da Política Setorial de Educação.(RECIFE, 1993, p. 19).

Um importante passo na implementação da participação popular nas atividades sobre a política educacional aconteceu através da Lei $n^{\circ}$ 15.547/ 91, que estabeleceu que o Plano Diretor de Desenvolvimento da Cidade do Recife viabilizasse a criação da Conferência Municipal de Educação (Comude), tendo sua primeira edição em 1993. A Comude "constitui instância colegiada de avaliação do desempenho da política educacional do município e de proposição de diretrizes e metas para o sistema municipal de educação" (RECIFE, 1993, p. 17).

Essa instância colegiada é considerada um dos principais avanços que compõem o cenário político do município, zelando pela presença da participação popular e a educação na perspectiva do direito, "em razão que é composta por entidades representativas da sociedade, dos poderes legislativo e executivo, professores, 
servidores e estudantes da rede municipal de ensino" (RECIFE, 1993, p. 17).

Até o momento desta pesquisa, já foram realizadas onze edições da Comude e, ao longo das suas edições, alguns mecanismos para garantia da gestão democrática se consolidaram, também foram discutidos diversos temas presentes na pauta da educação nacional e seus desdobramentos na educação do município. Nessa pauta, destacamos a transição da educação infantil assistencialista para a perspectiva do direito, na tomada de consciência de que a legislação não é uma referência estanque, mas a inauguração de uma nova etapa na educação municipal, o que reverberou na ampliação dos atendimentos nas creches e na pré-escola, organizando as questões pedagógicas com diálogos amplos e abertos às comunidades. Durante esse percurso, alguns documentos foram elaborados sobre a Política de Ensino Municipal e a Política de Ensino para a Educação Infantil, ressignificando o ensino, além de trazer novas perspectivas.

As Conferências Municipais de Educação representam um avanço no tocante à participação popular e fortaleceram a política municipal de educação, inclusive no que diz respeito à gestão democrática. Por exemplo, a $7^{\text {a }}$ Comude, realizada em 2009, com o tema Construção articulada do sistema nacional de ensino e Plano Nacional de Educação, propôs mudanças na metodologia de trabalho, do documento base formulado pelo MEC, que posteriormente foi enviada à Conferência Nacional de Educação 2010; a $8^{a}$ Comude, realizada em agosto de 2011, com o tema Educação em Movimento: Construção do Plano Decenal de Educação, discutiu as prioridades para a educação municipal, através da política de ensino, e as metas e estratégias pertinentes para o Plano Nacional de Educação; e a $9^{a}$ Comude, realizada em julho de 2013, com o tema O PNE na articulação do Sistema Nacional de Educação: compromisso de todos na garantia de uma educação de qualidade, propôs mudanças no Plano Nacional de Educação (PNE 2014-2024), ainda em tramitação para a aprovação no Congresso Nacional, que posteriormente foram encaminhadas à Conferência Estadual de Educação e em seguida à Conferência Nacional de Educação (Conae). 
Em sua penúltima edição, a $10^{\mathrm{a}}$ Conferência, realizada em maio de 2015, foi construído o dispositivo mais robusto para a educação municipal, o Plano Municipal do Recife - PME Recife, com vigência de 10 anos (2015-2025), detentor de características de Política de Estado e concebido em assembleia coletiva entre os representantes dos diversos segmentos que compõem a esfera municipal, onde foram nomeados membros constituintes de uma comissão que presidiria o Fórum Municipal de Educação, responsável por elaborar uma minuta e encaminhá-la para a construção do texto final que seria conduzido à Câmara dos Vereadores do Recife, em forma de projeto de lei. A votação aconteceu em 22 de junho de 2015, criando a Lei n $18.147 / 15$, publicada no dia seguinte no Diário Oficial do Município.

O PME Recife é instituído por 13 artigos e 20 metas e estratégias, que dialogam nos objetivos para os atendimentos na educação municipal, conforme as etapas e modalidades de ensino com responsabilidade do município. A concepção de infância e da educação infantil municipal é definida na Meta 01, que propõe:

Universalizar, até 2016, a educação infantil na préescola para as crianças de 4 (quatro) a 5 (cinco) anos de idade e ampliar a oferta de educação infantil em creches de forma a atender $70 \%$ (setenta por cento) da demanda das crianças de até ( três) anos até o final da vigência deste PME. (RECIFE, 2015)

Esse extrato de lei indica quais esforços do município do Recife serão destinados e a perspectiva da educação infantil como direito da criança, independentemente de sua condição socioeconômica. No documento, o reforço sobre a participação das comunidades e o zelo às condições técnicas surge na Meta 19:

Assegurar condições para a efetivação da gestão democrática da educação, associada a critérios técnicos de mérito e desempenho e a consulta à comunidade escolar, no âmbito das escolas públicas, prevendo recursos e apoio técnico da União para tanto. (RECIFE, 2015) 
A meta também tem reforço na seguinte estratégia:

19.3) estimular, na rede de educação básica, a constituição e o fortalecimento de grêmios estudantis e associações de pais, provendo, inclusive, espaços adequados e condições de funcionamento nas escolas e fomentando a sua articulação orgânica com os conselhos escolares, por meio das respectivas representações. (RECIFE, 2015)

A última edição, a $11^{\text {a }}$ Comude, realizada em março de 2018, sob o tema A consolidação do sistema nacional de educação e o Plano de Educação: monitoramento, avaliação e proposição de políticas para a garantia do direito à educação de qualidade social, pública, gratuita e laica, contou com a participação de diversos segmentos da sociedade na discussão sobre proposições do município, que deveriam ser enviadas à Conferência Estadual e em seguida à Conferência Nacional de Educação.

Desse modo, compreendemos que a manutenção da participação da comunidade local é inerente à ação democrática conquistada ao longo do processo evolutivo da sociedade contemporânea. No entanto, não isenta de vigilância a manutenção desse direito, para que nenhuma instância colegiada seja menosprezada. O reforço encontrado no município do Recife potencializa a história escrita sobre o pioneirismo do município quanto à participação popular.

\section{CONSIDERAÇÕES FINAIS}

O debate aqui buscou discorrer sobre as políticas para educação infantil e a participação da comunidade na cidade do Recife. Na argumentação, observamos algumas especificidades desse município nas iniciativas de envolvimento com a comunidade, que resultaram em diversos frutos, alicerçados no amplo diálogo entre a representação governamental e a participação popular e objetivando a promoção de políticas municipais educativas, entre elas o atendimento à educação infantil. Essa etapa da educação no Brasil 
sofre ainda hoje com fragilidades no campo dos investimentos, mas a busca por um atendimento de qualidade continua uma constante. A experiência do município do Recife revela a busca de mecanismos para atender às demandas locais, especialmente com parceiras com a comunidade, assegurando a autonomia e gestão democrática e a influência do poder local nas decisões.

Dessa forma, é possível inferir que as políticas públicas resultam em diferentes desenhos quando apoiadas em processos que envolvem a comunidade local nas decisões. As creches comunitárias são exemplos, por um lado, de ações que envolvem a sociedade e o Estado na busca de atendimento educacional e, por outro lado, revelam um período histórico de luta por educação infantil e creche para todos. Assim, são espaços de resistência e pressionam o poder público na oferta de mais espaços e pressionam o poder público na oferta de mais espaços educativos para a população.

As experiências revelam que tal movimento é capaz de proporcionar mudanças no contexto de formulação das leis e orientações para a elaboração das metas e estratégias que balizam a educação local. Cabe ao poder público também a garantia do direito popular em participar e decidir as ações, como vimos na experiência analisada ao propor Conselhos Municipais e Conferências Municipais para educação, assim, é possível uma maior aproximação entre a comunidade local e o poder público.

\section{REFERÊNCIAS}

ARIÉS, P. A descoberta da infância. In: ARIÉS, P. História Social da Criança e da família. $2^{\mathrm{a}}$ ed. Rio de Janeiro: LTC, 2006

BARDIN, L. Análise de conteúdo, [1977]. Lisboa: Edições 70 LDA, 2009.

BOBBIO, N. Política. In: BOBBIO, Norberto; MATEUCCI, Nicola; PASQUINO, Gianfranco. Dicionário de Política. Brasília, DF: Editora Universidade de Brasília, 1995.

BRASI. Constituição da República Federativa do Brasil: texto constitucional promulgado em 05 de outubro de 1988, com as 
alterações determinadas pelas emendas constitucionais de revisão $n^{\circ} 1$ a 6/94, pelas emendas Constitucionais $n^{\circ} 1 / 92$ a 91/2016 e pelo decreto legislativo $n^{\circ}$ 186/2008. Brasília: Senado Federal, coordenação de Edições Técnicas, 2016. 496 p.

BRASIL. Emenda constitucional n 14, de setembro de 1996. Modifica os arts. 34, 208, 211 e 212 da Constituição Federal e dá nova redação ao art. 60 do Ato das Disposições Constitucionais Transitórias. Brasília, DF: Presidência da República, 1996a. Disponível em:

http://www.planalto.gov.br/ccivil_03/Constituicao/Emendas/Emc/em c14.htm. Acesso em: abril 2020.

BRASIL. Lei $\mathbf{n}^{\circ} \mathbf{1 0 . 1 7 2}$, de 9 de janeiro de 2001. Aprova o Plano Nacional de Educação e dá outras providências. Brasília, DF:

Presidência da República, 2001. Disponível em:

http://www.planalto.gov.br/ccivil_03/leis/leis_2001//10172.htm.

Acesso em: maio 2020.

BRASIL. Lei no 11.494/07 de 20 de junho de 2007. Regulamenta o Fundo de Manutenção e Desenvolvimento da Educação Básica e de Valorização dos Profissionais da Educação - FUNDEB. Brasília, DF:

Presidência da República, 2007. Disponível em:

http://www.planalto.gov.br/ccivil_03/_Ato2007-

2010/2007/Lei/L11494.htm. Acesso: abril 2020.

BRASIL. Lei no 13.005/14 - Plano Nacional de Educação e legislação correlata e complementar. Supervisão editorial por Jair Lot Vieira. 6. ed. rev. atual. ampl. São Paulo: EDIPRO, 2013. (Série Legislação)

BRASIL. Lei $\mathbf{n}^{\circ}$ 9.394, de 20 de dezembro de 1996. Estabelece as diretrizes e bases da educação nacional. Brasília, DF: Presidência da República, 1996c. Disponível em:

http://www.planalto.gov.br/ccivil_03/leis/19394.htm. Acesso em: maio 2020.

BRASIL. Lei $\mathbf{n}^{\circ}$ 9.424, de 24 de dezembro de 1996. Dispõe sobre o Fundo de Manutenção e Desenvolvimento do Ensino Fundamental e de Valorização do Magistério, na forma prevista no art. $60, \S 7^{\circ}$, do Ato das Disposições Constitucionais Transitórias, e dá outras 
providências. Brasília, DF: Presidência da República, 1996b.

Disponível em: http://www.planalto.gov.br/ccivil_03/LEIS/L9424.htm. Acesso em: abril 2020.

GOULART, J. O. O orçamento participativo e a gestão democrática no poder local. Lua Nova: Revista de Cultura e Política, São Paulo, n. 69, p. 49-78, 2006.

HERMANY, R.; FRANTZ, D. O poder local na implementação de políticas públicas garantidoras de cidadania: Uma abordagem constitucional. Âmbito Jurídico, São Paulo, n. 58, 2008.

LUDKE, M.; ANDRÉ, M. E. D. A. Pesquisa em educação: abordagens qualitativas. São Paulo: EPU, 1986. (Temas Básicos de Educação e Ensino)

MULLER, P.; SUREL, Y. A análise das políticas públicas. Tradução por Agemir Bavaresco e Alceu R. Ferraro. Pelotas: Educat, 2002. p. 11-30.

RECIFE. Secretaria de Educação. Documento sobre a pré-escola municipal: definição política e proposta curricular. Recife, 1988a. (mimeo-impresso).

RECIFE. Lei $n^{\circ} 18.147$ de 23 de junho de 2015. Aprova o Plano Municipal de Educação. Diário Oficial do Município de Recife: Poder Executivo, Recife, ano XLIV, n. 70, p. 3, 23 jun. 2015.

Disponível em:

http://200.238.101.22/docreader/docreader.aspx?bib=R20150623\&p asta $=J$ unho\Dia\%2023. Acesso em: março 2020.

RECIFE. Lei $\mathbf{n}^{\circ}$ 15.547, de 19 de dezembro de 1991. Estabelece as Diretrizes Gerais em Matéria de Política Urbana, institui o Plano Diretor de Desenvolvimento da Cidade do Recife, cria o Sistema de Planejamento e de Informações da Cidade e dá outras providências. 1991.Disponível em:

http://www.legiscidade.recife.pe.gov.br/lei/15547/ . Acesso em: 30 março de 2020.

RECIFE. Lei Orgânica do Município do Recife, de 04 de abril de 1990. Recife: Câmara Constituinte Municipal do Recife, 1990. 
Disponível em: www.legiscidade.recife.pe.gov.br/lei/organica. Acesso em: março 2020.

RECIFE. Secretaria de Educação, Esporte e Lazer. Cadernos de Educação - Conselho Escolar, nº 03. Recife, 1993, 22 p

RECIFE. Secretaria de Educação. Caderno Melhoria da Qualidade de Ensino. Fóruns-debate. Recife, 1993. 25 p. (Série Caderno Municipal de Educação SEC/PCR)

RECIFE. Secretaria de Educação. O povo mesmo fala, escreve... Conta sua história. Um modo de praticar educação. Recife, ano 01, n. 2, dez. 1988b. 131 p. (Caderno de Educação Municipal).

SECCHI, L. Políticas Públicas: conceitos, esquemas de análise, casos práticos. 2.ed. São Paulo: Cengage Learning, 2016.

Submetido em: Junho/ 2020.

Aceito em: Março/ 2021. 